\title{
PEMBATALAN PUTUSAN BADAN PENYELESAIAN SENGKETA KONSUMEN MELALUI PENGADILAN NEGERI
}

\author{
Darwis Manurung \\ Fakultas Hukum Universitas Borneo Tarakan \\ Email: darwismanurung@yahoo.co.id
}

\begin{abstract}
Litigation dispute resolution is the settlement of a dispute through a court which results in a win and lose decision. The decision gives the one party wins and the other party loses. Non-litigation dispute resolution is the settlement of a dispute outside the court where it produces a win-win solution.

Based on the Decree of the Minister of Industry and Trade of the Republic of Indonesia Number: 350 / MPP / Kep / 12/2001 concerning Implementation of Duties and Authorities of the Consumer Dispute Settlement Agency Article 3 Letter a states that the dispute resolution process in BPSK can be pursued in three ways, namely by means of Conciliation, Mediation or Arbitration. Through these three ways of resolving it is expected to produce a decision that provides a win-win solution for the parties. However, it is inevitable that in reality not all decisions made by BPSK with this arbitration will give satisfaction to the parties.

The purpose of writing this paper is to find out the authority of the District Court to cancel the BPSK Decision and also know how to file an objection to the BPSK Decision.

The authority of the District Court to cancel the BPSK Arbitration verdict is based on Article 58 UUPK and Article 41 paragraph (3) Decree of the Minister of Industry and Trade of the Republic of Indonesia Number $350 /$ MPP / Kep / 12/2001.

Keyword: Litigation, Consumer, Law
\end{abstract}

\section{PENDAHULUAN}

\section{A. Latar Belakang}

Era globalisasi para pelaku bisnis memerlukan cara penyelesaian sengketa yang efektif untuk segera menyelesaikan sengketanya. 
Penyelesaian sengketa yang kita kenal saat ini terdiri dari penyelesaian secara nonlitigasi dan penyelesaian secara litigasi. Penyelesaian sengketa secara litigasi adalah penyelesaian sengketa melalui pengadilan dimana menghasilkan putusan yang bersifat menang dan kalah (win-lose). Putusan tersebut memberikan pihak yang satu menang dan pihak lain kalah. Penyelesaian sengketa secara nonlitigasi adalah penyelesaian sengketa di luar pengadilan dimana menghasilkan putusan yang bersifat menangmenang (win-win solution). Penyelesaiannya akan memberikan keuntungan bagi para pihak sehingga tidak ada pihak yang dirugikan.

Penyelesaian sengketa secara litigasi memerlukan waktu yang relatif lama dibandingkan dengan penyelesaian sengketa secara nonlitigasi yang relatif cepat. Waktu yang relatif lama pada proses penyelesaian sengketa secara litigasi akan berdampak pada biaya selama proses penyelesaiannya yang relatif mahal, sebaliknya pada penyelesaian sengketa secara nonlitigasi biaya yang diperlukan cenderung relatif murah dibandingkan dengan litigasi.

Berdasarkan hal tersebut, saat ini penyelesaian sengketa secara nonlitigasi menjadi pilihan penyelesaian sengketa yang paling disukai oleh para pelaku bisnis karena dinilai sebagai cara yang paling serasi dengan kebutuhan dalam dunia bisnis serta efektif dan efisien dalam proses penyelesaiannya guna menyelesaikan sengketa yang sesuai dengan keinginan dan kebutuhan mereka.

Dalam praktek bisnis terjadi sengketa antara pelaku usaha dengan konsumen. Sengketa konsumen terjadi karena adanya ketidakpuasan konsumen terhadap suatu produk atau kerugian yang dialami konsumen karena penggunaan atau pemakaian barang atau jasa. Secara khusus penyelesaian sengketa yang terjadi antara pelaku usaha dan konsumen ditetapkan berdasarkan Pasal 49 Undang-Undang Nomor 8 Tahun 1999 tentang Perlindungan Konsumen (selanjutnya disingkat UUPK) melalui Badan Penyelesaian Sengketa Konsumen (selanjutnya disingkat BPSK). 
BPSK merupakan suatu lembaga yang menyelesaikan sengketa konsumen antara pelaku usaha dengan konsumen yang sifat penyelesaiannya adalah win-win solution guna mencari jalan keluar terbaik bagi kedua belah pihak yang bersengketa. Proses penyelesaian sengketa konsumen melalui BPSK menggunakan pihak ketiga yang berkapasitas sebagai penengah di antara kedua belah pihak yang bersengketa. Pihak ketiga dalam hal ini harus berada di posisi netral dan tidak memihak kepada salah satu pihak.

Berdasarkan Keputusan Menteri Perindustrian dan Perdagangan Republik Indonesia Nomor: 350/MPP/Kep/12/2001 tentang Pelaksanaan Tugas dan Wewenang Badan Penyelesaian Sengketa Konsumen Pasal 3 Huruf a menyebutkan bahwa proses penyelesaian sengketa di BPSK dapat ditempuh melalui tiga cara yakni dengan cara Konsiliasi, Mediasi atau Arbitrase. Melalui ketiga cara penyelesaian tersebut diharapkan akan menghasilkan putusan yang memberikan win-win solution bagi para pihak. Walaupun demikian, tidak dapat dihindari bahwa kenyataannya tidak semua putusan yang dihasilkan BPSK dengan arbitrase ini akan memberikan kepuasan pada para pihak.

Sebagaimana telah ditetapkan bahwa putusan BPSK yang putusannya final and binding ternyata masih dapat dimintakan pembatalannya kepada Pengadilan Negeri dan Putusan BPSK tersebut dapat dibatalkan melalui putusan Pengadilan Negeri.

Berdasarkan latar belakang, maka yang menjadi permasalahan yang akan dibahas dalam makalah ini adalah:

1. Kewenangan Pengadilan Negeri membatalkan Putusan BPSK?.

2. Cara Mengajukan Keberatan terhadap Putusan BPSK?.

\section{B. Tujuan Penelitian}

Adapun tujuan penulisan makalah ini adalah untuk mengetahui kewenangan Pengadilan Negeri membatalkan Putusan BPSK dan juga mengetahui cara mengajukan keberatan terhadap Putusan BPSK. 


\section{ISI MAKALAH}

\section{A. Metode Penulisan}

Jenis penelitian yang digunakan dalam penulisan ini adalah metode normatif. Pendekatan masalah yang digunakan dalam penulisan ini adalah pendekatan perundang-undangan dan teori hukum.

\section{B. Tinjauan Pustaka}

\section{Tinjauan tentang BPSK}

\section{a. Tugas dan Wewenang Badan Penyelesaian Sengketa}

\section{Konsumen}

UUPK memberikan pedoman bagi konsumen atau pelaku usaha yang akan menyelesaikan sengketa secara nonlitigasi. Menurut Pasal 49 Ayat 1 UUPK disebutkan bahwa Pemerintah membentuk BPSK di kota atau kabupaten untuk penyelesaian sengketa konsumen di luar pengadilan atau secara nonlitigasi. ${ }^{11}$

Dengan demikian, penyelesaian sengketa di BPSK tidak diselesaikan melalui pengadilan dan menggunakan prinsip alternatif penyelesaian sengketa. Secara khusus, fungsi BPSK adalah sebagai alternatif penyelesaian sengketa konsumen di luar pengadilan, dan lembaga ini dibentuk di kabupaten/kota.

Adapun tugas dan wewenang BPSK menurut Pasal 52 UUPK meliputi:

a. Melaksanakan penanganan dan penyelesaian sengketa konsumen dengan cara melalui mediasi atau arbitrasi atau konsiliasi.

11 Wahyu Sasongko, Hukum Perlindungan Konsumen, Bandar Lampung: Universitas Lampung, 2007, hlm. 146. 
b. Memberikan konsultasi perlindungan konsumen.

c. Melakukan pengawasan terhadap pencantuman klasula baku.

d. Melaporkan kepada penyidik umum apabila terjadi pelanggaran kententuan dalam undang-undang ini.

e. Menerima pengaduan baik tertulis maupun tidak tertulis, dari konsumen tentang terjadinya pelanggaran terhadap perlindungan konsumen.

f. Melakukan penelitian dan pemerikasaan sengketa perlindungan konsumen.

g. Memanggil pelaku usaha yang diduga telah melakukan pelanggaran terhadap undang-undang perlindungan konsumen.

h. Memanggil dan menghadirkan saksi, saksi ahli dan/atau setiap orang yang dianggap mengetahui pelanggaran terhadap undang-undang ini.

i. Meminta bantuan penyidik untuk menghadirkan pelaku usaha, saksi, saksi ahli atau setiap orang yang sebagaimana dimaksud para huruf g dan huruf $h$, yang tidak bersedia memenuhi panggilan badan penyelesaian sengketa konsumen.

j. Mendapatkan, meneliti dan/atau menilai surat, dokumen, atau alat bukti lain guna penyelidikan dan/atau pemeriksaan.

k. Memutuskan dan menetapkan ada atau tidak adanya kerugian di pihak konsumen;

1. Memberitahukan putusan kepada pelaku usaha yang melakukan pelanggaran terhadap perlindungan konsumen; 
m. Menjatuhkan sanksi administratif kepada pelaku usaha yang melanggar ketentuan undang-undang ini.

\section{b. Keanggotaan BPSK}

Selanjutnya tentang keanggotaan BPSK terdiri dari unsur pemerintah, unsur konsumen, dan unsur pelaku usaha. Anggota setiap unsur berjumlah sedikit-dikitnya 3 orang dan sebanyak-banyaknya 5 orang. Pengangkatan dan pemberhentian anggota BPSK ditetapkan oleh Menteri. Adapun mengenai pelaksanaan tugas dan wewenang BPSK diatur lebih lanjut dalam Surat Keputusan Menteri Perindustrian dan PerdaganganNomor. 350/MPP/Kep/12/2001 tentang Tata Cara Penyelesaian Sengketa Konsumen melalui BPSK.

\section{Proses Penyelesaian Sengketa Melalui BPSK}

Merujuk ketentuan Pasal 52 huruf a UUPK dan Pasal 4 Surat Keputusan Menteri Perindustrian dan Perdagangan Republik Indonesia Nomor 350/MPP/Kep/2001 ditegaskan bahwa tugas dan wewenang BPSK melaksanakan penanganan dan penyelesaian sengketa dengan cara melalui mediasi atau arbitrase atau konsiliasi. Pasal 4 Surat Keputusan Menteri Perindustrian dan Perdagangan Republik Indonesia Nomor 350/MPP/Kep/2001 menegaskan penyelesaian sengketa konsumen oleh BPSK melalui cara mediasi atau konsiliasi atau arbitrase dilakukan atas pilihan dan persetujuan para pihak yang bersangkutan. Artinya, proses penyelesaian sengketa konsumen ini bukan merupakan proses penyelesaian 
sengketa secara bertahap atau berjenjang melainkan para pihak dapat bersepakat memilih bentuk penyelesaian yang mana yang akan digunakan.

Penyelesaian sengketa konsumen dengan cara konsiliasi dilakukan sendiri oleh para pihak yang bersengketa dengan didampingi oleh majelis yang bertindak pasif sebagai konsiliator. Penyelesaian secara mediasi, maka penyelesaian sengketa konsumen akan dilakukan sendiri oleh para pihak yang bersengketa dengan didampingi oleh majelis yang bertindak aktif sebagai mediator. Apabila para pihak sepakat memilih secara konsiliasi maupun mediasi, keduanya harus dilakukan dalam perjanjian tertulis yang ditandatangani oleh para pihak yang bersengketa dan dikeluarkan dalam bentuk keputusan BPSK. Sedangkan jika memilih penyelesaian secara arbitrase, maka penyelesaian sengketa konsumen akan dilakukan sepenuhnya dan diputuskan oleh majelis yang bertindak sebagai arbiter.Ketentuan mengenai pihak yang melakukan penyelesaian ini diatur dalam Pasal 5 Surat Keputusan Menteri Perindustrian dan Perdagangan Republik Indonesia Nomor 350/MPP/Kep/2001.

Majelis dibentuk oleh Ketua BPSK, yang jumlah anggotanya ganjil dan sedikitdikitnya 3 yang memenuhi semua unsur, yang unsur pemerintah, unsur pelaku usaha dan unsur konsumen, serta dibantu oleh seorang panitera. Putusan majelis bersifat final dan mengikat. Adapun yang dimaksud dengan putusan majelis bersifat final adalah tidak ada upaya banding dan kazasi. Sedangkan mengikat memiliki makna bahwa putusan akan mengikat para pihak untuk dilaksanakan sebagaimana mestinya. 
Penyelesaian sengketa konsumen oleh BPSK wajib dilaksanakan selambat-lambatnya dalam waktu 21 hari kerja, terhitung sejak permohonan diterima oleh sekretariat BPSK. Apabila salah satu pihak tidak puas dengan hasil putusan majelis dapat mengajukan keberatan kepada Pengadilan Negeri selambat-lambatnya dalam waktu 14 hari kerja terhitung sejak pemberitahuan putusan majelis diterima oleh para pihak yang bersengketa.

Keberatan terhadap putusan BPSK diatur dalam Peraturan Mahkamah Agung Nomor 01 Tahun 2006 tentang Tata Cara Pengajuan Keberatan terhadap Putusan BPSK. Bahwa dengan demikian maka keberatan adalah upaya bagi pelaku usaha dan konsumen yang tidak menerima putusan BPSK. Dalam Pasal 2 Peraturan Mahkamah Agung Nomor 01 Tahun 2006 ditegaskan bahwa keberatan tersebut hanya dapat diajukan terhadap putusan arbitrase yang dikeluarkan oleh BPSK. Keberatan ini dapat diajukan baik oleh pelaku usaha dan/atau konsumen kepada pengadilan negeri di tempat kedudukan hukum konsumen.

\section{Tata Cara Persidangan BPSK}

Bahwa sebagaimana diatur dalam Pasal 15 sampai Pasal 17 Surat Keputusan Menteri Perindustrian dan Perdagangan Republik Indonesia Nomor 350/MPP/Kep/2001 dimana konsumen dapat mengajukan permohonan, baik secara tertulis maupun lisan melalui sekretariat BPSK. Permohonan tersebut dapat juga diajukan oleh ahli waris atau kuasanya apabila konsumen meninggal dunia, sakit atau telah berusia lanjut, belum dewasa, atau orang asing (warga negara asing). Permohonan yang diajukan 
secara tidak tertulis dicatat oleh sekretariat BPSK dalam suatu format yang disediakan, dan dibubuhi tanda tangan atau cap stempel oleh konsumen, atau ahli warisnya atau kuasanya dan kepada pemohon diberikan bukti tanda terima. Berkas permohonan tersebut, baik tertulis maupun tidak tertulis yang dinilai telah memenuhi persyaratan, antara lain: memenuhi syarat sebagai sengketa konsumen, termasuk dalam wilayah hukum kewenangan BPSK yang bersangkutan, dilampiri dengan foto copy bukti bukti dan identitas pemohon, kemudian dicatat oleh sekretariat BPSK dan dibubuhi tanggal dan nomor registrasi.

Apabila hal permohonan diterima, maka permohonan itu diteruskan kepada Ketua BPSK untuk dipelajari dilanjutkan dengan penetapan Majelis BPSK yang akan memeriksa dan menyidangkan sengketa konsumen itu, selanjutnya menetapkan hari/tanggal persidangan dan memerintahkan pemanggilan para pihak. Di dalam Pasal 26 sampai Pasal 36 Surat Keputusan Menteri Perindustrian dan Perdagangan Republik Indonesia Nomor 350/MPP/Kep/2001 dapat diketahui bahwa Ketua BPSK memanggil pelaku usaha secara tertulis disertai dengan salinan permohonan penyelesaian sengketa konsumen, selambat-lambatnya dalam waktu 3 hari kerja sejak permohonan penyelesaian sengketa diterima secara benar dan lengkap. Majelis bersidang pada hari, tanggal dan jam yang telah ditetapkan, dan dalam persidangan majelis wajib menjaga ketertiban jalannya persidangan.

Sebagaimana proses penyelesaian sengketa yang menjadi pilihan para pihak untuk digunakan ada 3( tiga) yakni konsiliasi atau mediasi atau 
arbitrase. Di awal persidangan pertama Majelis BPSK menjelaskan adanya pilihan itu kepada pihak pihak, dan mereka dapat memilih salah satu untuk cara penyelesaian sengketa konsumen yang mereka sedang hadapi itu. Masing-masing dari bentuk penyelesaian tersebut memiliki karakteristik dan tata cara tersendiri. Bentuk penyelesaian yang pertama yaitu konsiliasi. Konsiliasi adalah proses penyelesaian sengketa konsumen di luar pengadilan dengan perantaraan BPSK untuk mempertemukan para pihak yang bersengketa dan penyelesaiannya diserahkan kepada para pihak.

Mengenai tata cara persidangan secara konsiliasi diatur dalam Pasal 28 Surat Keputusan Menteri Perindustrian dan Perdagangan Republik Indonesia Nomor 350/MPP/Kep/2001 yang dalam hal ini majelis mempunyai tugas:

a. Memangggil konsumen dan pelaku usaha yang bersangkutan.

b. Memanggil saksi dan saksi ahli bila diperlukan.

c. Menyediakan forum bagi konsumen dan pelaku usaha, perihal peraturan perundang-undangan dibidang perlindungan konsumen.

Bentuk penyelesaian sengketa yang kedua yaitu mediasi. Mediasi adalah proses penyelesaian sengketa konsumen di luar pengadilan dengan perantaraan BPSK sebagai penasihat dan penyelesaiannya diserahkan kepada para pihak. Mengenai tata cara persidangan secara konsiliasi diatur dalam Pasal 30 Surat Keputusan Menteri Perindustrian dan Perdagangan Republik Indonesia Nomor 350/MPP/Kep/2001. Dalam persidangan dengan cara mediasi, majelis mempunyai tugas:

a. Memanggil konsumen dan pelaku usaha yang bersengketa.

b. Memanggil saksi dan saksi ahli bila diperlukan. 
c. Menyediakan forum bagi konsumen dan pelaku usaha yang bersengketa.

d. Secara aktif mendamaikan konsumen dan pelaku usaha yang bersengketa.

e. Secara aktif memberikan saran atau anjuran penyelesaian sengketa konsumen sesuai dengan peraturan perundang-undangan di bidang perlindungan konsumen.

Bentuk penyelesaian sengketa yang ketiga yaitu arbitrase. Arbitrase adalah proses penyelesaian sengketa konsumen di luar pengadilan yang dalam hal ini para pihak yang bersengketa menyerahkan sepenuhnya penyelesaian sengketa kepada BPSK. Mengenai tata cara persidangan secara konsiliasi diatur dalam Pasal 32 sampai Pasal 36 Surat Keputusan Menteri Perindustrian dan Perdagangan Republik Indonesia Nomor 350/MPP/Kep/2001. Dalam penyelesaian sengketa konsumen dengan cara arbitrase, para pihak memilih arbiter dari anggota BPSK yang berasal dari unsur pelaku usaha, unsur pemerintah dan konsumen sebagai anggota majelis. Arbiter yang dipilih oleh para pihak, kemudian memilih arbiter ketiga dari anggota BPSK yang berasal dari unsur pemerintah sebagai ketua majelis.

Pada hari persidangan pertama, ketua majelis wajib mendamaikan kedua belah pihak yang bersengketa, dan ketika tidak tercapai perdamaian, maka persidangan dimulai dengan membacakan isi gugatan konsumen dan surat jawaban pelaku usaha. Ketua majelis memberikan kesempatan kepada konsumen dan pelaku usaha yang bersengketa untuk menjelaskan hal-hal yang persengketakan. Pada persidangan tersebut, sebelum pelaku usaha memberikan jawabannya, konsumen dapat mencabut gugatannya dengan membuat surat pernyataan. Apabila gugatan dicabut oleh konsumen, maka dalam persidangan, pertama majelis wajib mengumumkan bahwa gugatan dicabut. Apabila dalam proses penyelesaian sengketa konsumen terjadi 
perdamaian antara konsumen dan pelaku usaha yang bersengketa, majelis membuat putusan dalam bentuk penetapan perdamaian.

Ada kemungkinan kedua pihak ataupun salah satu pihak tidak hadir pada hari/tanggal sidang yang ditentukan. Dalam hal pelaku usaha dan konsumen tidak hadir pada hari persidangan pertama majelis memberikan kesempatan terakhir kepada konsumen dan pelaku usaha untuk hadir pada persidangan kedua dengan membawa alat bukti yang diperlukan. Persidangan kedua diselenggarakan selambat-lambatnya dalam waktu 5 hari kerja terhitung sejak hari persidangan pertama dan diberitahukan dengan surat panggilan kepada konsumen dan pelaku usaha oleh sekretariat BPSK. Apabila pada persidangan kedua, konsumen tidak hadir, maka gugatannya dinyatakan gugur demi hukum, sebalikmya bila pelaku usaha yang tidak hadir, maka gugatan konsumen dikabulkan oleh majelis tanpa kehadiran pelaku usaha.

Hasil penyelesaian sengketa konsumen dengan konsiliasi atau mediasi dibuat dalam perjanjian tertulis yang ditandatangani oleh konsumen dan pelaku usaha. Perjanjian tertulis dikuatkan dengan keputusan majelis yang ditandatangani oleh ketua dan anggota majelis.

Secara khusus penyelesaian konsumen dengan cara arbitrase dibuat dalam bentuk putusan majelis yang ditandatangani oleh ketua dan anggota majelis. Majelis wajib menyelesaikan sengketa konsumen selambatlambatnya dalam waktu 21 hari kerja terhitung sejak gugatan diterima oleh BPSK. Ketua BPSK memberitahukan putusan majelis secara tertulis kepada alamat konsumen dan pelaku usaha yang bersengketa, selambat-lambatnya 7 hari kerja sejak putusan dibacakan. Konsumen dan pelaku usaha yang bersengketa wajib menyatakan menerima dan menolak putusan BPSK dalam waktu 14 hari kerja terhitung sejak putusan BPSK diberitahukan. Konsumen dan pelaku usaha yang menolak putusan BPSK dapat mengajukan keberatan kepada pengadilan negeri selambat-lambatnya dalam waktu 14 hari kerja terhitung sejak keputusan BPSK dibacakan. 
Selain itu, pelaku usaha yang menyatakan menerima putusan BPSK, wajib melaksanakan putusan tersebut selambat-lambatnya dalam waktu 7 hari kerja terhitung sejak menyatakan menerima putusan BPSK. Pelaku usaha yang menolak putusan BPSK, tetapi tidak mengajukan keberatan, setelah batas waktu 7 hari dianggap menerima putusan dan wajib melaksanakan putusan selambat-lambatnya 5 hari kerja setelah batas waktu mengajukan keberatan dilampaui.

Namun, bagi pihak yang merasa dirugikan dengan adanya putusan BPSK dapat mengajukan permohonan keberatan agar dapat dilakukan pembatalan terhadap putusan BPSK tersebut oleh Pengadilan negeri wajib mengeluarkan putusan atas keberatan dalam waktu paling lambat 21 hari sejak diterimanya keberatan. Selanjutnya terhadap putusan pengadilan negeri tersebut, para pihak dalam waktu paling lambat 14 hari dapat mengajukan kazasi ke Mahkamah Agung. Mahkamah Agung wajib mengeluarkan putusan dalam waktu paling lambat 30 hari sejak menerima permohonan kazasi.

\section{HASIL DAN PEMBAHASAN}

\section{Kewenangan Pengadilan Negeri Membatalkan Putusan BPSK}

Pasal 54 ayat 3 UUPK jo. Pasal 42 ayat 1 Keputusan Menperindag Nomor 350/MPP/Kep/12/2001 menentukan bahwa putusan Majelis Badan Penyelesaian Sengketa Konsumen (BPSK) bersifat final dan mengikat. Pada penjelasan Pasal 54 ayat 3 UUPK ditegaskan bahwa kata bersifat final itu berarti tidak ada upaya banding dan kasasi.

Selanjutnya dalam Pasal 41 ayat (3) Keputusan Menteri Perindustrian dan Perdagangan Republik Indonesia Nomor 350/MPP/Kep/12/2001, menyatakan bahwa konsumen atau pelaku usaha yang menolak putusan BPSK, dapat mengajukan keberatan kepada Pengadilan Negeri selambatlambatnya dalam waktu 14 (empat belas) hari ketiga terhitung sejak keputusan BPSK diberitahukan. Para pihak ternyata masih bisa mengajukan keberatan ke Pengadilan Negeri paling lambat 14 hari setelah pemberitahuan 
putusan BPSK. Hal ini bertentangan dengan sifat putusan BPSK yang bersifat final dan mengikat.

Pembatalan putusan arbitrase dapat diartikan sebagai suatu upaya hukum yang diberikan kepada para pihak yang bersengketa untuk meminta kepada Pengadilan Negeri agar suatu putusan arbitrase dibatalkan, baik terhadap sebagian atau seluruh isi putusan. ${ }^{12}$ Oleh sebab itu, dalam proses pembatalan putusan arbitrase, pengadilan tidak berwenang untuk memeriksa pokok perkara. Kewenangan pengadilan terbatas hanya pada kewenangan memeriksa keabsahan prosedur pengambilan putusan arbitrase, antara lain proses pemilihan arbiter hingga pemberlakuan hukum yang dipilih oleh para pihak dalam penyelesaian sengketa. ${ }^{13}$ Dengan dimungkinkan upaya hukum banding dan selanjutnya kasasi, maka sebenarnya pembentuk undang-undang sebenarnya bersikap tidak konsisten. Penjelasan Pasal 54 ayat 3 tidak konsisten dengan rumusanrumusan Pasal 58 Undang - Undang Perlindungan Konsumen (UUPK).

Putusan arbitrase BPSK, meskipun digunakan terminologi arbitrase tetapi Undang - Undang Perlindungan Konsumen (UUPK) sama sekali tidak mengatur mekanisme arbitrase seperti yang ditentukan dalam Undang Undang Nomor 30 Tahun 1999 Tentang Arbitrase Dan Alternatif Penyelesaian Sengketa, melainkan membuat suatu aturan tersendiri yang relative berbeda dengan apa yang ditentukan dalam dalam UU No. 30 Tahun 1999. Menyebabkan timbulnya pertentangan antara arbitrase dalam putusan BPSK, dengan putusan arbitrase dalam Undang - Undang Nomor 30 Tahun 1999 Tentang Arbitrase Dan Alternatif Penyelesaian Sengketa, yang memerlukan penafsiran lebih lanjut. Sehubungan dengan fiat eksekusi muncul masalah lain yaitu pengaturan Keputusan Menteri Perindustrian dan Perdagangan Republik Indonesia Nomor 350/MPP/Kep/12/2001, yang menyatakan bahwa terhadap putusan BPSK dimintakan penetapan eksekusi

\footnotetext{
${ }^{12}$ Munir Fuady, Arbitrase Nasional: Alternatif Penyelesaian Sengketa Bisnis, Bandung: Citra Aditya, 2000, hlm. 10.

${ }^{13}$ Ibid., hlm. 85.
} 
oleh BPSK kepada pengadilan negeri ditempat konsumen yang dirugikan. Pengaturan semacam ini dalam hokum acara perdata tidak lazim, karena permohonan penetapan eksekusi adalah demi kepentingan pihak yang dimenangkan dalam putusan. Oleh karena itu yang seharusnya mengajukan permohonan penetapan eksekusi adalah pihak yang berkepentingan sendiri bukan lembaga BPSK.

\section{Cara Mengajukan Keberatan terhadap Putusan BPSK}

Permohonan pembatalan putusan arbitrase yang diajukan oleh para pihak diatur dalam Pasal 70 Undang - Undang Nomor 30 Tahun 1999 Tentang Arbitrase Dan Alternatif Penyelesaian Sengketa. Pasal tersebut menyatakan bahwa terhadap putusan arbitrase para pihak dapat mengajukan permohonan pembatalan apabila putusan tersebut diduga menggunakan unsur-unsur, yaitu sebagai berikut:

1. Surat atau dokumen yang diajukan dalam pemeriksaan, setelah putusan dijatuhkan, diakui palsu atau dinyatakan palsu.

2. Setelah putusan diambil ditemukan dokumen yang bersifat menentukan, yang disembunyikan oleh pihak lawan.

3. Putusan diambil dari hasil tipu muslihat yang dilakukan oleh salah satu pihak dalam pemeriksaan sengketa.

Alasan-alasan pengajuan permohonan pembatalan putusan arbitrase bersifat alternatif, artinya masing-masing alasan dapat digunakan sebagai dasar untuk mengajukan permohonan pembatalan putusan arbitrase. Berdasarkan ketentuan tersebut, Pasal 70 Undang - Undang Nomor 30 Tahun 1999 Tentang Arbitrase Dan Alternatif Penyelesaian Sengketa hanya mengatur alasan-alasan yang dapat digunakan oleh para pihak yang bersengketa untuk mengajukan permohonan pembatalan putusan arbitrase. ${ }^{14}$

\footnotetext{
${ }^{14}$ Ibid., hlm. 86.
} 
Berdasarkan Pasal 71 Undang - Undang Nomor 30 Tahun 1999 Tentang Arbitrase Dan Alternatif Penyelesaian Sengketa permohonan pembatalan putusan arbitrase harus diajukan secara tertulis dalam waktu paling lama 30 hari terhitung sejak hari penyerahan dan pendaftaran putusan arbitrase kepada Panitera Pengadilan Negeri. Kemudian Pasal 72 Undang - Undang Nomor 30 Tahun 1999 Tentang Arbitrase Dan Alternatif Penyelesaian Sengketa menyatakan bahwa permohonan pembatalan putusan arbitrase harus diajukan kepada Ketua Pengadilan Negeri. Apabila permohonan dikabulkan, Ketua Pengadilan Negeri menentukan lebih lanjut akibat pembatalan seluruhnya atau sebagian putusan arbitrase. Putusan atas permohonan pembatalan ditetapkan oleh Ketua Pengadilan Negeri dalam waktu paling lama 30 hari sejak permohonan.

Terhadap putusan Pengadilan Negeri dapat diajukan permohonan banding ke Mahkamah Agung yang memutus dalam tingkat pertama dan terakhir. Mahkamah Agung mempertimbangkan serta memutuskan permohonan banding dalam waktu paling lama 30 hari setelah permohonan banding tersebut diterima oleh Mahkamah Agung.

Menyikapi adanya permasalahan hukum tentang putusan Badan Penyelesaian Sengketa Konsumen (BPSK), melalui Mahkamah Agung dengan tujuan untuk menyamakan persepsi pada seluruh lembaga peradilan, maka diterbitkannya Peraturan Mahkamah Agung Nomor 1 Tahun 2006 Tentang Tata Cara Pengajuan Keberatan Terhadap Putusan Badan Penyelesaian Sengketa Konsumen. Putusan Badan Penyelesaian Sengketa Konsumen (BPSK) bersifat final dan mengikat dan pada hakikatnya tidak dapat diajukan keberatan, kecuali dipenuhi syarat-syarat tertentu yang diatur dalam Peraturan Mahkamah Agung Nomor 1 Tahun 2006.

Selanjutnya Peraturan Mahkamah Agung Nomor 1 Tahun 2006 Tentang Tata Cara Pengajuan Keberatan Terhadap Putusan Badan Penyelesaian Sengketa Konsumen menegaskan bahwa upaya hukum keberatan yang diajukan konsumen atau pelaku usaha hanya dapat dilakukan 
terhadap putusan arbitrase yang dikeluarkan oleh BPSK, tidak meliputi putusan BPSK yang timbul dari konsiliasi dan mediasi. Adapun syarat-syarat pengajuan keberatan atas putusan BPSK :

1. Keberatan diajukan dalam bentuk gugatan (bukan voluntair) sebagaimana diatur dalam Peraturan Mahkamah Agung RI Nomor 1 Tahun 2006.

2. Keberatan diajukan dalam tenggang waktu 14 (empat betas) hari kerja sejak Pelaku Usaha atau konsumen menerima pemberitahuan putusan BPSK.

3. Keberatan diajukan dalam rangkap 6 (enam) untuk dikirim oleh Panitera kepada pihak yang berkepentingan termasuk BPSK.

4. Keberatan diajukan melalui Kepaniteraan Pengadilan Negeri di tempat kedudukan hukum Pelaku Usaha atau Konsumen sesuai dengan prosedur pendaftaran perkara perdata.

5. BPSK bukan merupakan pihak.

Tata cara pengajuan keberatan terhadap putusan Badan Penyelesaian Sengketa Konsumen :

1. Keberatan diajukan dalam tenggang waktu 14 (empat betas) hari kerja terhitung sejak pelaku usaha atau konsumen menerima pemberitahuan putusan BPSK.

2. Keberatan terhadap putusan arbitrase BPSK dapat diajukan apabila memenuhi persyaratan sebagaimana diatur dalam Pasal 70 UndangUndang No.8 Tahun 1999, yaitu:

a. Surat atau dokumen yang diajukan dalam pemeriksaan, setelah putusan dijatuhkan diakui palsu atau dinyatakan palsu.

b. Setelah putusan Arbitrase BPSK diambil ditemukan dokumen yang bersifat menentukan, yang disembunyikan pihak lawan.

c. Putusan diambil dari hasil tipu muslihat yang dilakukan oleh salah satu pihak dalam pemeriksaan sengketa. 
3. Ketua Pengadilan Negeri menunjuk majelis Hakim yang mempunyai pengetahuan cukup di bidang perlindungan konsumen.

4. Dalam hal keberatan diajukan atas dasar sebagaimana dimaksud dalam butir 2 di atas, Majelis Hakim dapat mengeluarkan pembatalan putusan BPSK.

5. Dalam hal keberatan diajukan atas dasar alasan lain di luar ketentuan sebagaimana dimaksud dalam butir 3 di atas, Majelis Hakim dapat mengadili sendiri sengketa konsumen yang bersangkutan.

6. Pemeriksaan keberatan dilakukan hanya atas dasar putusan BPSK dan berkas perkara.

7. Dalam hal mengadili sendiri Majelis Hakim wajib memperhatikan ganti kerugian sebagaimana diatur dalam Pasal 19 ayat (2) Undang-Undang No.8 Tahun 1999.

8. Majelis Hakim harus memberikan putusan dalam waktu 21 (dua puluh satu) hari kerja sejak sidang pertama.

9. Upaya hukum terhadap putusan keberatan atas putusan BPSK adalah kasasi.

\section{KESIMPULAN}

A. Kewenangan Pengadilan Negeri untuk membatalkan putusan Arbitrase BPSK didasarkan pada Pasal 58 UUPK dan Pasal 41 ayat (3) Keputusan Menteri Perindustrian dan Perdagangan Republik Indonesia Nomor 350/MPP/Kep/12/2001.

B. Cara mengajukan pembatalan putusan BPSK diatur dalam Peraturan Mahkamah Agung Nomor 1 Tahun 2006 Tentang Tata Cara Pengajuan Keberatan Terhadap Putusan Badan Penyelesaian Sengketa Konsumen 


\section{DAFTAR PUSTAKA}

\section{A. Buku}

Fuady, Munir. Arbitrase Nasional: Alternatif Penyelesaian Sengketa Bisnis. Bandung: Citra Aditya. 2000.

Harahap, M. Yahya. Arbitrase. Jakarta: Sinar Grafika. 2003.

-Hukum Acara Perdata. Jakarta: Sinar Grafika. 2012.

---------------------Hukum Acara Perdata Indonesia. Bandung: PT Citra Aditya Bakti. 2012.

Kristiyanti, Celina Tri Siwi, 2008, Hukum Perlindungan Konsumen, Sinar Grafika, Jakarta.

Nugroho, Susanti Adi, 2011,Proses Penyelesaian Sengketa Konsumen, Prenada Media Group, Jakarta.

Sarwono, Hukum Acara Perdata: Teori dan Praktik. Jakarta: Sinar Grafika. 2011.

Soemartono, Gatot. Arbitrase dan Mediasi di Indonesia. Jakarta: PT Gramedia Pustaka Utama. 2006.

\section{B. Peraturan Perundang-undangan}

Undang-Undang Nomor 8 Tahun 1999 tentang Perlindungan Konsumen Tambahan Lembaran Negara Republik Indonesia Nomor 3821

Undang-Undang Nomor 30 Tahun 1999 tentang Arbitrase dan Alternatif Penyelesaian Sengketa Tambahan Lembaran Negara Republik Indonesia Nomor 3872 
Keputusan Menteri Perindustrian dan Perdagangan Republik Indonesia Nomor : 350/MPP/Kep/12/2001 tentang Pelaksanaan Tugas dan Wewenang Badan Penyelesaian Sengketa Konsumen.

Peraturan Mahkamah Agung Nomor 1 Tahun 2006 tentang Tata Cara Pengajuan Keberatan terhadap Keputusan Arbitrase yang Dikeluarkan oleh BPSK. 